\title{
Family Education Thoughts in Zhang Ling's Novels
}

\author{
Ting Ye \\ Jinan University \\ Guangzhou, China
}

\begin{abstract}
The famous new immigrant writer Zhang Ling showed her rich family education thoughts in her novels. The female protagonists in Zhang Ling's novels are mostly intellectuals, many of whom have received a good education and can mange on their own. Their achievements are inseparable from good family education. Personality and quality of parents have a profound impact on their children's education. The secret of family education lies in one word of love. In multiple-child families, love can't be unequal. Through her novel creation, Zhang Ling has shown a wealth of family education ideas, which is of practical inspiration and teaching significance.
\end{abstract}

\section{Keywords—Zhang Ling; family education; teaching}

\section{INTRODUCTION}

Family education is a problem that we will all face and a problem that we must seriously solve. It is a very important content in social life. Literary works write stories about family education through visual text, which is enough to make our understanding of family education deeper.

After Yan Geling and Hong Ying, many immigrant writers with different personalities appeared in the new immigrant literary world. Among them, Zhang Ling is an influential new immigrant novelist in recent years, together with Yan Geling and Hong Ying, People call them the "Troika" that leads in overseas Chinese literature. Zhang Ling's novel presents a gratifying situation of vigorous development.

Zhang Ling, born in Wenzhou, Zhejiang province, studied in Canada since 1986, and now lives in Toronto, Canada, where she is in charge of a hearing clinic of a hospital. Zhang Ling has been writing in her spare time since 1991, her works involve short, medium-length and long novels, as well as a large number of essays and translations. Her representative works include "Aftershock", "Empty Nest", "Accompanying Father and Mother", "Sisters From Shanghai", "Year's Pursuit Home", "Beyond the Dream", "Mail Order Bride", "Gold Mountain Blues", and "A Single Swallow". Mr. Liu Jun, a well-known critic of Chinese literature, believes that "Zhang Ling is a very outstanding representative writer in Chinese literature of North America."[1]

In Zhang Ling's writing tradition, family education thought have always occupied an important position, even a central position. Zhang Ling's novel fully shows the importance of family education. "The Book of Changes" states: "If every family is good, then the world is good." The "Da Xue" said: "Family is unified and then the country is ruled." This article studies the family education ideas in Zhang Ling's novels. It is divided into three parts. The first part analyzes the relation of family education with children's success, the second part analyzes the role of parents in family education, the third part shows that love is the most important in family education, and love can't be unequal in multiple-child families.

\section{CHILDREN'S SUCCESS IS INSEPARABLE FROM GOOD FAMILY EDUCATION}

To a certain extent, Zhang Ling's novel is a family novel. The novel focuses on writing the different personality characteristics and life trajectories of children in the family. These are inseparable from the impact of the family education they receive. Family education has the most profound impact on children's growth. "Among the numerous and complicated social and environmental factors, the most direct, profound and lasting influence on the psychological development of a person is the family environment."[2] "Many psychological studies have already proven that early life experiences, especially native families, play a vital role in personal character, and will have a long-term and profound impact on personal life, some even determine his or her lifetime happiness."'[3]

Zhang Ling wrote a lot of successful children. Children are the hope of a family, Wang Xiaodeng in Zhang Ling's novel "The Aftershock" is a famous writer, Song Moyan in "Year's Pursuit Home" is an engineer, and Juan Lian in "Sisters From Shanghai" is a successful boss, and Wang Yue is a famous painter and Ta Qing is a doctor, Jiang Juanjuan in "The Mail Order Bride" finally became a fashion designer, Xuan Ning in "Beyond the Dream" is a successful businesswoman and $\mathrm{Su}$ Ning is a nurse... They all have achieved something. They are hardworking, self-disciplined, dedicated, with dreams and dare to fight. Even children who have not done much in their careers are successful in running a family. The children represent the glory of a family, and the daughters in Zhang Ling's writing have basically done to add glory to the family. The successful family education behind this is worthy of our study.

The future of their children is related to the rise and fall of the family, so Chinese families have always valued education. Families in Zhang Ling's writing all values education, many of the mothers are descendants of the noble family, and they attach great importance to the education of their daughters. Huang Xinyue, the mother in "Year's Pursuit Home" is the daughter of a landlord's family, her daughter Song Moyan studied abroad; Qin Er, the mother in "Sisters From Shanghai" is a descendant of capitalist Jin Sanyuan, and her eldest daughter Juan Lian is the boss of a restaurant, her second daughter Wang Yue is a well-known painter, and her third 
daughter Ta Qing is a doctor; Jin Feiyun in "Beyond the Dream" is also a descendant of a big capitalist, her daughter Xuan Ning is a boss lady and Su Ning is a nurse ... These mothers are all descendants of the Noble Family, although their family has fallen for historical reasons, the tradition of the Noble Family that values education has passed down. The family has a good family education and cultural atmosphere. Children's education is related to the economic situation of the family, because education is based on a certain economic foundation. Generally, middle-class families have a leisurely and poetic family life, and their children can get a good education. What is the ideal state of a family? The answer is, of course, varied. A rich family environment is undoubtedly one of them, children and mothers may be born aristocrats, and this family environment is what many people desired. It is loved by us, but it is difficult and very hard for many people to achieve. And because these families are from the Jiangnan region, they have also absorbed the good customs of the Jiangnan region. "The cultural families in Jiangnan, especially in Jiangsu and Zhejiang, they totally ignored the saying that" women have no talent is virtue." Female members of the family are given not only a relatively relaxed living space, but also a loose education that is no different from that of men."[4]

The children in Zhang Ling's novels are all seeking knowledge and progress, and take pride in learning knowledge. The important content of family education is to attach importance to encouraging children to work hard to learn scientific and cultural knowledge. Their parents are successful people who can help their children maintain a constant thirst for knowledge and enterprising. We should recognize the changing role of education in children. The family is the central place to educate children, and it is an important way to educate. The purpose of education is to change temperament, remove evil, preserve truth, and restore humanity. The teaching methods of parents are mainly gradual, heuristic, teaching according to their aptitude, and mainly positive education. The requirements for the child's method of learning are to have ambition first, then they have to work hard, read many books, and pay attention to self-reflection at all times. Not only benefited from the family education and school education that they received during their youth, but also benefited from the lifelong education they received after they entered society.

The family education in Zhang Ling's novels attaches importance not only to the children's knowledge education, but also to their moral education. Generally speaking, the cultural connotation of education can include knowledge education, emotional education, aesthetic education and other aspects. Family education has an important impact on a person's growth. Children are immature, and immaturity means children's dependence and plasticity. Parents must not only let all their children receive the best education and stimulate their enthusiasm for knowledge, but also educate their children well and have strict requirements on their children based on noble human nature. They teach their children to form a good selfimage and overcome their bad habits. Moral education is important to what kind of person a child becomes, and to form an ideal personality.
In addition, families also value other education for their children. "Character education is the foundation of children's life, and it belongs to a spiritual aspect; the teaching of livelihood skills is a socially based means, which belongs to a material aspect." [5] Families attach great importance to the training of their children's ability to running a house, that is, the cultivation of the so-called "inside master".

Parents and children form a mutual-benefit relationship in teaching, which is conducive to family harmony. "A good intergenerational relationship between parents and children is an equal and harmonious parent-child relationship. It requires parents to have modern education concepts, scientific education methods, healthy psychology, and a good lifestyle."[6] "Children's independent thoughts are manifested as independent behaviors. The premise of independence is respect, respect for their ideas and opinions, and treating them as people with independent thoughts. We must not only respect the child's autonomy, but also show respect for the child's choice."[7] The mutual influence of children is also a very important part. "Tai Gong Jia Jiao" said: "Keep good men company and you shall be of the number."

\section{PARENTS Play AN IMPORTANT ROLE IN EDUCATING THEIR CHILDREN}

In family education, parents' education to their children is undoubtedly the first important thing. Traditional Confucian morality has always valued individual moral cultivation. Clan is a place for individuals to practice morality and the starting point of their moral cultivation. Parents, as the inheritors and executors of traditional moral sense, teach and supervise their children. The parenting style is very important to the formation of a child's character and personality. Parents are the model for their children's speech and behavior, and they are the role models for children to follow. The quality of parental behavior affects their life attitudes and has a direct impact on their lives. "Family is the earliest classroom for children, the initial environment for the formation of behavioral habits, and parents are the children's enlightenment teachers."[8]

The personality of parents has a great impact on children's education. Parents have influenced their children's psychological development since they were born. Marx and Engels pointed out: "Child's ability to develop depends on the development of the parent." [9] Family is the place where children are most affected and most directly educated, family is the first environment for children to become successful, parents are the child's first teacher and a lifelong teacher. "Parents are the most frequent and direct imitation objects of their children." [10] Family is children's enlightenment school, and parents are the best teachers for their children. The words and deeds of parents and the way in which they live are very influential in the growth of children. Family education is a kind of education work in which the parents teach by example as the main education method in the daily life. Parents' teaching needs to be persuasive only if the parents fit their words and deeds, and subtly educate themselves, so that their children can feel deeper. "In real life, many living facts show that parents' outlook on life and ideological character have a great influence on the effect of children's education." [11] Parents' outlook on life and ideological character are 
manifested as value orientation in daily life, as to what to pursue and what means they use to pursue. When dealing with the relationships and problems of people and things around them, the attitudes of parents often have a profound impact on the way their children behave. "The premise of the art of family education is that parents must lead by example; in a sense, parenting by example is an art of education itself, or the most important and superb educational art."[12]

The success of family education depends on the quality of the parents. Parents' self-cultivation is of great significance to successfully educate their children. Parents' cultural competence has an important impact on their children's learning and moral education, and the two are generally directly proportional. "Parents' personalities directly affect and significantly control the family's emotions and relationships." [13] The factors such as the personality, temperament, mood, and knowledge level also affect the way they raise their children. "Family education, although inevitably affected and restricted by society and the times, the determination of training goals is not exactly the same as school education, and it depends to a large extent on the will of parents, and influenced by the parents' experiences, ideological awareness, cultural competence, career, interest and hobby." [14]

The absence of father is the greatest harm to the child. It is undeniable that educating children is a common obligation of parents. "In terms of educating children, both father and mother have their own advantages. The two are indispensable, such as the two wheels of a car and the two wings of a bird."[15] "The natural differences between men and women make fathers more rational on many issues, while mothers are more emotional, fathers are relatively macro, and mothers are relatively micro."[16] Father is a very important role in family education. As we all know, the relationship between father and daughter is particularly important. For a child, father is of irreplaceable significance. There are many ways in which a father can enrich a child's life, and it is almost impossible to count. "When fathers and children play, children are more engaged, happier, more passionate, and more focused on their physique."[17] "When children enter puberty, it is a special responsibility for their father to introduce them to the world and talk about the future."[18] Whether it is participating in housework, exchanging emotions, or talking about the future and planning life, children must have a role model, and father is the best role model. Because of their father's constant attention and affection, children in secure attachment relationships understand their importance in this world. Children of this attachment type work well when they grow up, and can achieve ambitious career goals. The father's factor works in a number of ways. The absent fathers develop from emotional indifference to abandonment of their children, which can lead to deep sadness or anger of their children. This father's influence confuses the children, because half of their ego comes from the father, but the father gives up the responsibility of raising and accompanying them. Although it can be seen from the appearance, the fact is that children's career choices, behaviors, and abilities are strongly influenced by the absent fathers in childhood and adolescence. Anger is the natural reaction of a child with a lack of fatherly love to the emotional pain that is deep within him, because the father does not meet the child's natural needs for love, recognition, and security.

In the process of educating children, mothers spent a lot of effort, and the little bit of the child's growth process also brought a lot of inspirations to them. Confucius believed: "If you want to correct people, then you have to first correct yourself. If you are correct, then others will listen to you with you say anything. If you are not correct yourself, then they will not listen to you even if you give orders." Xunzi said: "Use kindness to guide people is teaching." Most men who support women study have a practical reason: knowledge can make women better mothers. Mothers are the educators for her children's whole life, the quality of the mother determines the quality of the child, and the quality of the child will determine the rise and fall of the family. In many families, mothers are the most influential people. Therefore, they are also responsible for many problems in raising children. Girls imitate their mothers, to learn how their mothers live, and the responsibility to be a mother. Mothers have a greater influence on their children's careers as adults. "In the traditional Chinese ethical order, blood relationship is of great significance for identity confirmation. Mothers usually play an authoritative role in the construction of their daughters' ethical identity." [19] Zhang Ling shaped a legendary great woman - A Jiu in the "Beyond the Dream". A Jiu started from a young maidservant and finally became the boss of Jin San Yuan Cloth Store. She has experienced ups and downs in her life,the only thing that never change is her fortitude. A Jiu is like a bamboo, with incomparable integrity and courage. Although A Jiu was a plain and weak woman, she carried the Jin's family on her own shoulder. In the many incidents of Jin's family, A Jiu showed her wisdom and sagacity, and endured all the sufferings. During the Land Reform and the Cultural Revolution, she worked hard to spare Jin's family from some persecutions. In the vision, thoughts, and Fei Yun's education, A Jiu's wisdom and vision were revealed. Under the raising of such mother, her daughter Jin Feiyun also became a woman with courage.

\section{LOVE SHOUld BE EQUAL AND FAIR IN MUltiPle- CHILD FAMILIES}

Although the daughters in Zhang Ling's novels have a successful career, the only thing that bothered is that they all have a common deficiency — the lack of love, the lack of love from family members, and the ability to love others. The formation of their personality is inseparable from their family atmosphere. "The relationship between family members, the atmosphere of family life and the order of life are especially important for minor children."[20] Their families are all lack of love. The mother is very strict, serious, behaves properly, and is too strict with her daughter. The father is either absent or often conflicts with the mother. This family type has no caring and harmonious, and lacks of a good family atmosphere. It is not an ideal family, even it is a tragic. "The degree and manner of parental love and concern for their children affects their physical and mental development."[21] Parents cannot love their children sincerely, and their children can feel it with instinct. Family education has a particularly large impact on the formation of a child's character. People who grow up in a family atmosphere without love will not be healthy. Love is 
"Psychologically speaking, jealousy is a targeted feeling that arises when the relationships of reality and expectations are threatened.'"[25] In multiple-child families, parents should treat their children equally, and try to balance their attitudes and management as much as possible. They should care, love and demand them equally.

\section{CONCLUSION}

The famous new immigrant writer Zhang Ling showed her rich family education thoughts through her literary creation: Parents should pay attention to their children's education of knowledge, morals and other aspects; fathers and mothers play an important and irreplaceable role in the growth of their children, and the profound impact on children cannot be overstated; the abundance of love in the family is the biggest driving force for children's education and also a source of power. In multiple-child families, fair and equal love should be given to children. The writer shows the multiple dimensions of family education in the form of literary images, giving people a profound inspiration.

\section{REFERENCES}

[1] Liu Jun: "Crossing and Blending: Cross-regional and Cross-cultura Chinese Literature in the World", Beijing: People's Literature Publishing Company, 2014, p. 270.

[2] Zhao Zhongxin: "Family Pedagogy: Science and Art of Educating Children", Beijing: People's Education Press, 2001, p. 26.

[3] Lin Hong, Wang Chengbiao: "Psychological Counseling for Parents and Children: Caring for the Child's Spiritual Growth", Beijing: Peking University Medical Press, 2011, p. 52.

[4] Wang Weiping, Yuan Yimei, "Research on the Modern Value of Chinese Traditional Mother Education Culture", Beijing: Modern Education Press, 2015, p. 62.

[5] Yan Aimin, "Family education in Ancient China", Beijing: Commercial Press, 2013, p. 075

[6] Sun Yunxiao: "Education starts with respect", Nanjing: Jiangsu Education Press, 2007, p. 2.

[7] Chen Daohua, "Korean Family Education: A Pillow Book for Quality Education That Changed Millions of Korean Families", Beijing: Rural Reading Press, 2006, p. 69

[8] Tang Xiangqi, "Classics of New Century Family Education", Beijing: China Youth Publishing Company, 2009, p. 3.

[9] "The Complete Works of Marx and Engels", Vol. 3, p. 498.

[10] Zhao Zhongxin, "Family Pedagogy: Science and Art of Educating Children", Beijing: People's Education Press, 2001, p. 244.

[11] Zhao Zhongxin, "Family Pedagogy: Science and Art of Educating Children", Beijing: People's Education Press, 2001, p. 137

[12] Zhao Zhongxin, "Family Pedagogy: Science and Art of Educating Children", Beijing: People's Education Press, 2001, p. 271.

[13] Lin Hong, Wang Chengbiao: "Psychological Counseling for Parents and Children: Taking Care of Child's Spiritual Growth", Beijing: Peking University Medical Press, 2011, pp. 50-51.

[14] Zhao Zhongxin, "Family Pedagogy: Science and Art of Educating Children", Beijing: People's Education Press, 2001, p. 98.

[15] Tang Xiangqi, "Classics of New Century Family Education", Beijing: China Youth Publishing Company, 2009, p. 46.

[16] Tang Xiangqi, "Classics of New Century Family Education", Beijing: China Youth Publishing Company, 2009, p. 49.

[17] Tang Xiangqi, "Classics of New Century Family Education", Beijing: China Youth Publishing Company, 2009, p. 47. f consequence of parental preference is jealousy, 
[18] Tang Xiangqi, "Classics of New Century Family Education", Beijing: China Youth Publishing Company, 2009, p. 47.

[19] Wang Xiaohui, "Thinking about Growth: The Expression of the Minor's Ethical Identity in 'The Bonesetter's Daughter'"[J], "Journal of Guangxi University for Nationalities (Philosophy and Social Science Edition)", 2017-01, p. 180.

[20] Zhao Zhongxin, "Family Education: Science and Art of Educating Children", Beijing: People's Education Press, 2001, p. 155.

[21] Zhao Zhongxin, "Family Pedagogy: Science and Art of Educating Children", Beijing: People's Education Press, 2001, p.142.

[22] [US] Su Jim Jenny Kim, “Why Asian Students Are Excellent”, translated by Jiang Lizhu, Beijing: China Book Publishing Company, 2007, p. 18.

[23] Edited by Wang Yichuan, "New Edition of Literary Criticism”, Beijing: Beijing Normal University Press, 2011, p.119.

[24] Zhao Zhongxin, "Family Pedagogy: Science and Art of Educating Children", Beijing: People's Education Press, 2001, p. 330.

[25] Edited by Xiong Zhehong, "I love, therefore I am: Love and love Psychology of Western Literature Masters", Beijing: Peking University Press, 2011, p. 15. 